\title{
From Liberal Globalisation to Economic Nationalism?
}

The election of Donald Trump, the UK's exit from the European Union, and strong challenges to the current ruling elites by populist parties in France, Greece, Holland, Hungary and Poland confront the neo-liberal ruling elites. These social movements, universally dubbed as 'populist', offer an electoral choice but we remain puzzled as to what policies they are likely to implement.

There are parallels with post-First World War Europe when John Maynard Keynes declared: 'The decadent international but individualistic capitalism, in the hands of which we found ourselves after the war, is not a success. It is not intelligent.... and it doesn't deliver the goods. In short, we dislike it, and we are beginning to despise it. But when we wonder what to put in its place, we are extremely perplexed' (National Self-Sufficiency 1933).

While contemporary counter movements differ in many respects, they all agree on a number of significant political and economic issues. First, a condemnation of the economic polices shared until now by the major electoral parties. Second, a criticism that the economic mechanism and political process have led to social polarisation. Third, a contention that electoral democracy has delivered an oligarchic bloc of irresponsible elites who have utilised neo-liberalism to legitimate their own interests.

\section{Scepticism of the Global Economic Order}

Such deficiencies lead to two political challenges: First, scepticism about the benefits of a global order. The way of thinking which dominates Western states-

1 The article is published on the website: https://research.sociology.cam.ac.uk/news/ liberal-globalisation-economic-nationalism. Reprinted with permission of the author.

(C) D.Lane, 2019 
men is global neo-liberalism. Global neo-liberalism involves the free movement between countries of labour, capital, goods and services. It is the market which should determine the allocation, combination and output of goods and services. The global market should ensure the effective use of resources, channelling capital and labour into their most efficient uses and profitable sources.

However, the outcomes of globalised markets do not resolve many incompatibilities and consequently they drive critical anti-establishment movements. Investment does not promote social development in places where it is most needed. As Keynes pointed out, the market does not achieve the optimum employment of labour. Though much global poverty has decreased, an increasing number of studies, ranging from economist Thomas Piketty to the IMF's Christine Lagarde, consider that inequality has increased to such a degree that it is slowing economic growth. The gap between rich and poor increases in the developed countries.

Donald Trump is a conspicuous leader who has deplored the social and political deficiencies of developments in the United States where there are 7.5 million people recorded as actively seeking work, widespread urban blight and high rates of interpersonal crime. The level of poverty can be estimated from the fact that over 43 million Americans received food vouchers under the Supplemental Nutritional Assistance Programme.

Trump here describes one of the richest countries in the world. Of course, not all these deficiencies can be attributed to 'globalisation', but clearly market mechanisms have not led to a desirable economic equilibrium. The operation of the market has led to recurring economic financial instability and, even in the rich states, to persistent and institutional forms of poverty.

Public opinion reflects such disenchantment. In 2017, in a study of the 28 member states of the European Union, pollsters found that 86 per cent of respondents considered that 'income inequality in [our] country' was either 'very serious' or 'somewhat serious'. (Project 28. 1000 respondents in each EU country, data collected 10 April to 31 May 2017. Available at: http://project28.eu/foreign-affairs-2017). When asked 'would you say altogether [that] globalisation, the rise of the global economy, is rather good or rather bad to your country?' In fifteen (UK, Spain, Portugal, Croatia, Slovakia, Slovenia, Austria, Italy, Hungary, Belgium, Czech Republic, Cyprus, France, Latvia and Greece) out of twenty eight countries less than half of the population rated the influence of the global economy as 'rather good'. Overall 79 per cent disagreed with the proposition that 'companies should move their production to where they can find the cheapest labour force, even if it causes job losses in your country'.

\section{State Management and Coordination}

The second challenge of the populist movements is that the economic mechanism should shift from global market coordination to state management. The conventional argument is that the unrestricted movement of capital, labour, goods and services will be resolved on the basis of the laws of 'comparative advantage'. If countries produce what they can do best and then exchange with others, the optimum level of production will be achieved. Labour and capital will move to where they receive the best returns. 
But the laws of comparative advantage reinforce the existing distribution of resources rather than any 'natural' division between different countries or areas. It will not automatically lead to investment and training which underdeveloped or declining regions require to give rise to new forms of production. Out-migration, 'getting what you deserve from the world' is the neo-liberal solution. This however has cumulative effects - it strengthens the strong economic areas and weakens the poor ones. Moscow and London become enriched; and Ivanovo and Ventspils destitute. Globally, poor unemployed people migrate from Africa to find work, even to declining areas of the European Union such as Greece - thus exacerbating the downward spiral of de-development.

What then is the alternative? If market coordination has been shown to lead to booms and slumps, enrichment and poverty, some form of administrative coordination is one alternative. Working within the existing global neo-liberal framework will not solve the problem. Moreover, as there are no democratic institutional forms which can provide the necessary coordination on a global scale, there remain statist forms of management. This is because the state is the only institution that has the legitimacy and sometimes (not always) the economic power to carry out systematic development with a long term perspective.

\section{Economic Nationalism}

At the heart of these political developments is economic nationalism which is a doctrine based on predispositions and policies which prioritize the maintenance and development of the domestic (national) economy. An underlying assumption of economic nationalism is that the people forming a nation enclosed within the geographical borders of a state have a common interest which transcends class or other social divisions within that state and takes precedence over linkages between domestic actors and foreign ones. The crucial component of economic nationalism is that national identities should determine economic outcomes. The objective of economic nationalism is to protect home industries and cultures from foreigners.

There is not one set of policies or institutions which uniquely defines 'economic nationalism'. Economic nationalism is a shell in which different economic philosophies may operate. The promotion of the interests of a nation state can be achieved by different political forms such as 'one nation' conservatism, autocratic corporatism, socialist planning, or through a social-democratic mixed economy. The state preserves and furthers the power of domestic economic interests. To secure its objectives the state utilises laws, such as tariffs and tax policies to influence the direction of trade, and direct control through ownership of assets and/or by shaping the conditions in which private capital and market mechanisms operate.

\section{Effects of Globalisation}

The globalised neo-liberal economy erected many obstacles to deter governments from pursuing policies promoting economic nationalism. Countries are subject to international trade treaties with organisations such as the WTO and to international agreements with mediators such as the IMF. These organisations 
secure neo-liberal conditions which preclude both state ownership and preferences for the award of contracts to domestic companies.

The power of such global restrictions has led some writers, such as Sam Pryke, to cast doubt on the very possibility of realising economic nationalism in the twenty-first century. The equalisation of tariffs though the WTO facilitated a qualitative change in the geographical mobility of the factors of production, and the ease of capital mobility has resulted in a significant rise of mergers and acquisitions. The size and importance of transnational companies have significantly increased. While transnationals have no single home their ownership is concentrated in the hegemonic Western companies - the G7 countries.

National laws to protect domestic workers (by enforcing minimum wages or employment rights) raise labour costs. Consequently, corporations seek alternative 'company friendly' regimes and transnational firms switch production from the home country to the foreign host. Hence whilst metropolitan companies and their owners benefit from remitted profits and fees, their previous employees become unemployed as production ceases in the home of the parent company. WTO agreements do not stipulate wage rates. Free mobility of labour favours capital by keeping down wage costs. In order to retain or attract companies, national governments may have to give financial guarantees to foreign corporations. Ironically perhaps, in such cases, economic nationalism, while preserving the domestic economy, concurrently rewards transnational companies and their foreign owners.

\section{The Trouble with Economic Nationalism}

While significant sections of the electorate in both the USA and Western Europe are currently captivated by populist policies, it remains to be seen whether state political leaders will be able to deliver the envisaged benefits of economic nationalism. Even US political elites led by Donald Trump are not independent actors but are organically linked to business classes. The administration seeks to promote American business and concurrently to maintain or even improve Donald Trump's electoral support.

Governments have the power to impose punitive tariffs on imports and award generous tax incentives to exporters. But there are limits to the administration's power - politically, constitutionally and economically. Even if successful in relocating supplies chains to the home countries, the days of armies of well-paid skilled and semi-skilled workers in manufacturing will never return. The nature of manufacturing has changed dramatically. Now production is highly mechanised and the installation of robots and other automated processes have significantly reduced the number of jobs and types of occupations. Developments over the past fifty years have shrunk the industrial labour force: between 1975 and 1990, the share of the labour force of the largest 500 US manufacturing companies dropped from 17 per cent to under 10 per cent. Foreigners were also buying up American assets: in 1977 only 3.5 per cent of manufacturing (by value) was owned by non-Americans, even by 1990 the figure had risen to 11 per cent. 


\section{The Changing Production Process}

The cross border nature of supply chains presents a major problem for economic nationalism, especially for complex engineering projects such as the construction of air liners and motor cars. Mexico's exports to the USA for example contain 40 per cent US content. Even simple commodities such as seat belts have the following chain: Mexican nylon is exported to Canada for weaving, and then returned to Mexico for cutting and installing into vehicles for export (to USA). For the construction of Boeing's Dreamliner literally thousands of parts are imported, involving not only aero engines but also design and other high tech services. Some of these work processes could be brought back to the USA, but not all.

Of even more importance is the fact that manufacturing industry has experienced significant changes in the production process and in the character and structure of the work force. There has been a massive long term shift from industry to services. The USA's industrial work force fell from 31 per cent in 1980 to 17 per cent in 2010. For comparison, Russia has followed the same trend, falling from 40 per cent in 1990 to 28 per cent in 2014, giving Russia still a substantial industrial working class.

Economists like Sergei Bodrunov are undoubtedly correct to argue that 'bringing back' industrial production to home countries would be beneficial and create more jobs. But industrial production would not recreate the conditions which in the post-war period secured an affluent American working class and in Russia a full employment economy. Levels of wages in manufacturing (for those in work) have declined in comparison with services and many of the previously high paying manual jobs have gone as a consequence of mechanisation.

The transnational nature of many corporations will significantly modify the promotion of 'national' interest within nation states. Favouring companies operating in the USA and penalising the imports of foreign firms through tariffs and taxation policy will increase employment of Americans but concurrently will also benefit foreign firms producing in the USA.

One crucial assumption of economic nationalism - that there is a common interest for all members of a nation - needs qualification in three major respects. Firstly, citizens in capitalist countries do not benefit equally from economic nationalism. The class structure generates significant inequalities derived from levels of skill, type of occupation and amount of ownership of assets. Secondly, manufacturing and services are dependent on networks which are international in scope and cannot be substituted or can only be replaced by national units at considerable cost. Maynard Keynes argued in his article on National Self-Sufficiency that the costs are worth paying, but companies trading for profit may not be willing to foot the bill. Thirdly, transnational corporations relocated in host countries not only benefit the host country but also their home country by repatriating profits.

One other political drawback of a corporate state, with businesses driven for profit, is that the state will carry the risks if enterprise fails, and the private sector will pocket the profits if commerce succeeds. Other more socialist forms of economic nationalism are yet to appear. If economic coordination could take place on the principles of planning and maximising public welfare, many of such disadvantages could be averted. 


\section{DAVID LANE \\ From Liberal Globalisation to Economic Nationalism?}

Contemporary counter movements, universally dubbed as 'populist' differ in many respects, but they all agree on a number of significant political and economic issues. First, a condemnation of the economic polices shared until now by the major electoral parties. Second, a criticism that the economic mechanism and political process have led to social polarisation. Third, a contention that electoral democracy has delivered an oligarchic bloc of irresponsible elites who have utilised neo-liberalism to legitimate their own interests.

Skepticism about the benefits of the global order is fueled by two political issues. First, the results of globalized markets do not solve many incompatibilities, and this leads to critical movements against the establishment. The second problem is that the economic mechanism must move from the coordination of the global market to public administration. If market coordination leads to booms and busts, enrichment and poverty, some form of administrative coordination is an acceptable alternative.

Such political events are associated with economic nationalism. However, a globalized neoliberal economy has created many obstacles to deter governments from pursuing policies promoting economic nationalism. In addition, there are limits to the power of administration - political, constitutional and economic. Anyway, it can be assumed that if economic coordination could be carried out on the principles of planning and maximizing public welfare, many of these problems could be solved.

Keywords: 'populist' counter movements, effects of globalization, economic nationalism, state management and coordination 